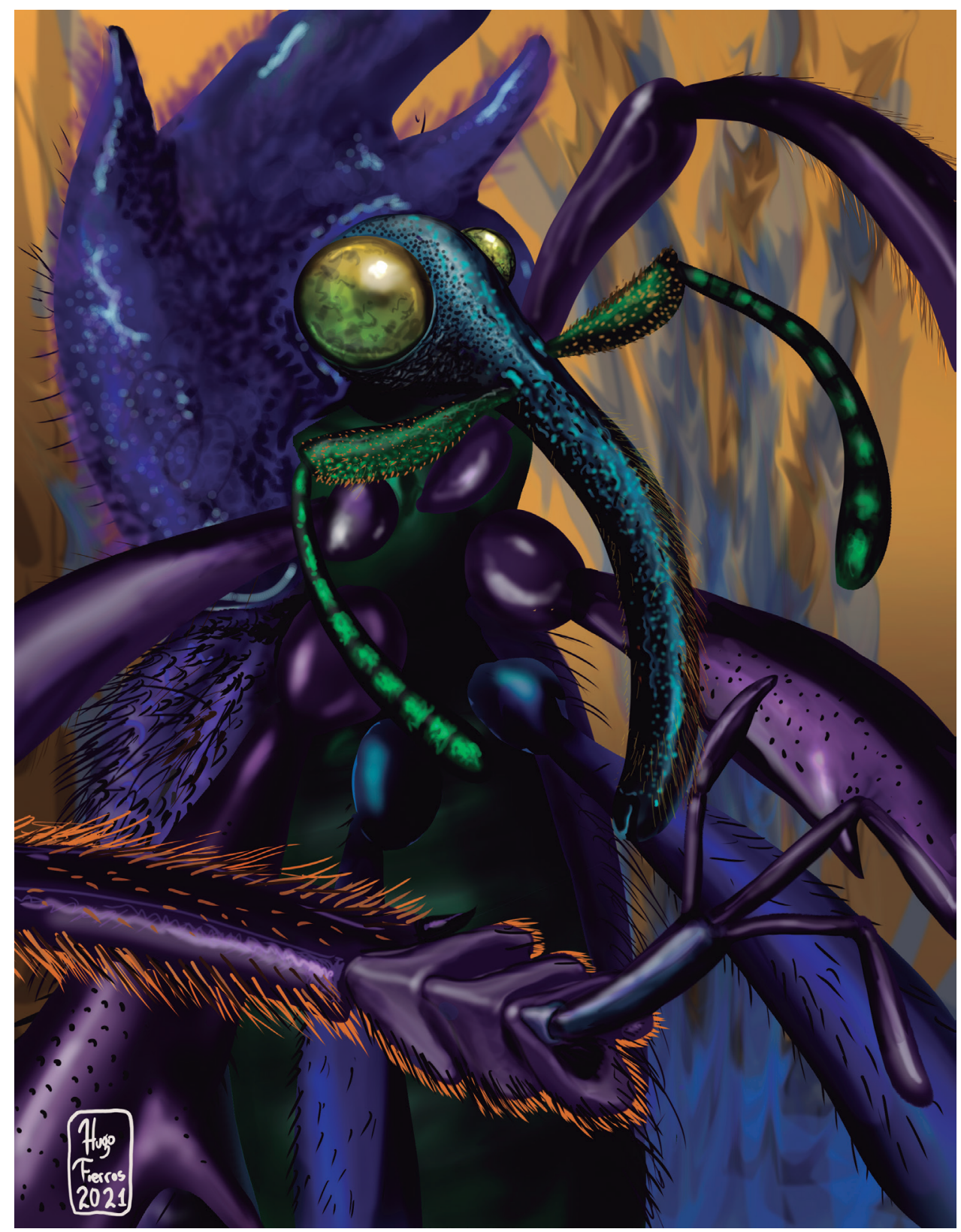

Dugesiana, Año 28, No. 2, (julio-diciembre, segundo semestre de 2021), es una publicación semestral, editada por la Universidad de Guadalajara, a través del Centro de Estudios en Zoología, por el Centro Universitario de Ciencias Biológicas y Agropecuarias. Camino Ramón Padilla Sánchez \# 2100, Nextipac, Zapopan, Jalisco, Tel. 37771150 ext. 33218, http://148.202.248.171/dugesiana/index.php/DUG/index, glenusmx@gmail.com. Editor responsable: José Luis Navarrete-Heredia. Reserva de Derechos al Uso Exclusivo 04-2009-062310115100-203, ISSN: 2007-9133, otorgados por el Instituto Nacional del Derecho de Autor. Responsable de la última actualización de este número: José Luis Navarrete-Heredia, Editor y Ana Laura González-Hernández, Asistente Editorial. Fecha de la última modificación 1 de julio de 2021, con un tiraje de un ejemplar.

Las opiniones expresadas por los autores no necesariamente reflejan la postura del editor de la publicación.

Queda estrictamente prohibida la reproducción total o parcial de los contenidos e imágenes de la publicación sin previa autorización de la Universidad de Guadalajara. 
Artículo

\title{
Notes on Stenochiini Kirby, 1837 genera and species from western North America (Coleoptera: Tenebrionidae)
}

\section{Notas sobre géneros y especies de Stenochiini Kirby, 1837 del oeste de Norteamérica (Coleoptera: Tenebrionidae)}

\author{
M. Andrew Johnston ${ }^{1,2^{*}}$ and Kevin A. Cortés Hernández ${ }^{1,3}$ \\ ${ }^{1}$ Biodiversity Knowledge Integration Center, Arizona State University, Tempe, AZ 85282, U.S.A. \\ 2ajohnston@asu.edu https://orcid.org/0000-0002-0166-6985 3kcortesh@asu.edu https://orcid.org/0000- \\ 0002-1150-9940
}

\begin{abstract}
The tribe Stenochiini Kirby, 1837 comprises six genera in North America with most species occurring in the tropical and temperate regions of the continent. Only two species in the genus Strongylium Kirby, 1818 have previously been reported from west of the Continental Divide in the United States from Arizona and New Mexico and no members of the tribe have been reported from the state of Sonora, Mexico. We here report Strongylium tenuicolle (Say, 1826), known to be widely distributed east of the Rocky Mountains, from west of the Continental Divide for the first time from both Arizona and New Mexico. We similarly report the first records of both Strongylium apache Triplehorn and Spilman, 1973 and Strongylium atrum Champion, 1888 from Sonora. Oploptera chamelensis (Doyen, 1990) was previously known only from the type series from Jalisco, Mexico and is here reported from Sonora, which thereby extends the known range of this genus significantly. To promote consistency in generic recognition, we propose the transfer of Oploptera simplicicollis (LeConte, 1878) New Combination from Strongylium for the species distributed across the southeastern United States. Species diagnoses are given, and generic boundaries are discussed along with the expected diversity of the Sonoran Desert region.
\end{abstract}

Keywords: Oploptera, Sierra Madre Occidental, Sky Islands, Sonoran Desert, Strongylium.

\section{RESUMEN}

La tribu Stenochiini Kirby, 1837 comprende seis géneros en Norteamérica, con la mayor parte de las especies distribuidas en las regiones tropicales y templadas del continente. Sólo dos especies del género Strongylium Kirby, 1818 han sido reportadas al oeste de la divisoria Continental en Arizona y Nuevo México, Estados Unidos, sin embargo, ningún miembro de la tribu había sido registrado en el estado de Sonora, México. En este trabajo se reporta por primera vez al oeste de la divisoria Continental en Arizona y Nuevo México, a la especie Strongylium tenuicolle (Say, 1826), conocida por estar ampliamente distribuida al este de las Rocallosas. Asimismo, se presentan nuevos registros de Strongylium apache Triplehorn y Spilman, 1973 y Strongylium atrum Champion, 1888 para Sonora. Además, Oploptera chamelensis (Doyen, 1990), únicamente conocida por la serie tipo de Jalisco, México es registrada para Sonora, extendiendo el rango de distribución del género de manera relevante. Con la finalidad de promover consistencia en la distinción de ambos géneros, se propone transferir Strongylium simplicicollis LeConte, 1878 al género Oploptera: Oploptera simplicicollis (LeConte, 1878) nueva combinación, especie distribuida al sureste de los Estados Unidos. Se presentan las diagnosis de las especies y además se discuten los límites genéricos a la par de la diversidad esperada de esta tribu de coleópteros en la región del desierto de Sonora.

Palabras clave: Oploptera, Sierra Madre Occidental, Sky Islands, desierto de Sonora, Strongylium.

Darkling beetles of the family Tenebrionidae Latrielle, 1802 are a conspicuous and diverse element of the entomofauna in the arid reaches of southwestern United States and northwestern Mexico (Aalbu et al. 2002, Bousquet et al. 2018, Johnston et al. 2018). The tribe Stenochiini Kirby, 1837 (subfamily Stenochiinae Kirby, 1837) comprises six genera in North America distributed primarily in the tropical and temperate regions (Triplehorn and Spilman 1973). West of the continental divide, the genus Strongylium Kirby, 1818 reaches the tribe's northwesternmost range with two species previously reported from southern Arizona and extreme southwestern New Mexico in the United States (Triplehorn and Spilman 1973). In Mexico, no species have ever been reported from the state of Sonora, one species of Strongylium from Sinaloa, and several species from multiple genera reported from the subtropical regions of Jalisco (Triplehorn and Spilman 1973, Doyen 1990, Bousquet et al. 2018).

The tribe was recharacterized and a key for the genera of North America was given by Doyen (1989). The tribe can be partially recognized from other Tenebrionidae by the presence of stellate antennal sensoria on the terminal seven or eight antennomeres, simple tarsal claws, and an elongate body form (Doyen 1989, Aalbu et al. 2002). They can be further and confidently diagnosed by the internal characters of the female spermatheca being sclerotized and spherical, and both sexes possessing short, saccate defensive reservoirs which lack annular folds (Doyen 1989, 
Johnston et al. 2020).

All species of Stenochiini recorded from the United States and Canada were treated by Triplehorn and Spilman (1973), whose key and diagnoses work well to identify the constituent species which were there all included in Strongylium. The fauna from Mexico through Panama was treated by Champion (1888), and the region of Chamela, Jalisco was treated by Doyen (1990).

Recently collected specimens from the southwestern United States and material from intensive collecting in Sonora, Mexico have generated several important records reported below. These newly understood distributions bring the genus Oploptera Chevrolat, 1844 (=Otocerus Mäklin, 1867, unjustified replacement name, see Bousquet et al. 2018: 316) much closer to the boundary of the United States. As such, we are compelled to reconsider the generic boundaries of Oploptera and Strongylium which prompted the generic transfer of one extralimital species from the southeastern United States.

\section{METHODS AND MATERIALS}

Specimens were examined with a Leica M125C stereomicroscope. Species were identified using the most recent treatments of Stenochiini from North America (Champion 1888, Triplehorn and Spilman 1973, Doyen 1990) and nomenclature follows Bousquet et al. (2018). Images were taken with a Passport imaging system from Dunn Inc. equipped with a Canon 5D camera and a Canon $65 \mathrm{~mm}$ macro lens. Multiple images from consecutive focal planes were taken and stacked into a single in-focus image using the Helicon Focus software package and final plates were edited using Adobe Photoshop.

The primary specimens used in this study are deposited in the Arizona State University Hasbrouck Insect Collection (ASUHIC) and the M. Andrew Johnston Research Collection (MAJC), both located in Tempe, Arizona USA. Additional specimen records were examined from the following available online aggregators: Global Biodiversity Information Facility (GBIF, www.GBIF.org); Symbiota Collections of Arthropods Network (SCAN, www.scanbugs.org); iNaturalist (www.iNaturalist.org); Bug Guide (www.BugGuide.net); and the Ecdysis portal (https://serv. biokic.asu.edu/ecdysis/). All new specimen data provided in this study were fully digitized and are publicly available from the Ecdysis portal, SCAN, and GBIF in their entirety. Standardized locality data are summarized for each species treated for new ranges reported herein. Distribution maps were generated using the observations acquired from SCAN and GBIF (GBIF 2021) and were augmented with literature records from Mexico. Additional state and county records for the United States found in earlier works (e.g., Triplehorn and Spilman 1973) and not represented by digitized specimen data are not included in the maps provided herein. Distribution maps were generated from the georeferenced digitized specimen records discussed above as visualized with SimpleMappr (Shorthouse 2010, www.simplemappr.net). New records are given with the number of exemplars examined and the collection they are deposited in. Image captions include the catalog number for the specimen imaged.

\section{SPECIES ACCOUNTS \\ Oploptera chamelensis (Doyen, 1990)}

(Fig. 1A,C)

Otocerus chamelensis Doyen, 1990: 256

Oploptera chamelensis: Bousquet et al. 2018: 317

Diagnosis. This species (Fig. 1A) of Oploptera can be separated from all other species of Stenochiini in the region (all belonging to the genus Strongylium) by the antennae with article 3 about half as long as 4 (equal or longer in other species) and the terminal 8 articles weakly serrate (Fig. 1C) (moderately elongate in other species). Body concolorous, shining black to chestnut brown often with aeneous tinge. Pronotum with weak lateral margin in anterior 1/5 only, unmargined thereafter.

Distribution. (Fig. 2) Previously known only from four specimens from the Estación de Biología Chamela, Jalisco (Doyen 1990). New Records. Mexico: Sonora: 10.7 km (by air) Northwest of Mazatán, Sierra Huertana [4 ASUHIC, 3 MAJC]; Sierra de Bacadéhuachi, El Rincón de Guadalupe Station [1 ASUHIC].

Remarks. The description of this species (Doyen, 1990) extended the range of Oploptera from Guatemala to Jalisco, Mexico. Our records extend the range some $1200 \mathrm{~km}$ NNW. We have not seen the types for this species; however, our specimens match the description of Doyen (1990) exactly and the habitat is largely contiguous between Chamela and the given localities in Sonora along the Sierra Madre Occidental. See the Discussion for comments on generic boundaries.

Strongylium apache Triplehorn and Spilman, 1973

(Fig. 3A,D)

Strongylium apache Triplehorn and Spilman, 1973: 10; Bousquet et al. 2018: 319

Diagnosis. This species (Fig. 3A) can be recognized from all other Stenochiini of the region by having antennal article 3 subequal to 4 , pronotum with a complete lateral margin in the form of a fine carina (Fig. 3D) (S. atrum lacks a lateral margin), elytra finely punctate, punctures not in impressed sulcus, intervals flat (S. terminatum with sulcate striae and convex intervals). Body concolorous, dull black.

Distribution. (Fig. 2) Known from southern Arizona and extreme southwestern New Mexico (Triplehorn and Spilman 1973). New Records. Mexico: Sonora: 15.9 km (by air) SE of Nacozari de Garcia, Sierra Juriquipa [1 ASUHIC] [New Country Record]. United States: Arizona: Maricopa County: Near Mount Ord, $33^{\circ} 55^{\prime} 19^{\prime \prime} \mathrm{N}$, $111^{\circ} 24^{\prime} 52^{\prime \prime}$ W [W.E. Steiner, personal communication, this specimen in the United States National Museum of Natural History represents a slight northern extension to the known 
range].

Remarks. This species is often sympatric with though much less frequently collected than $S$. atrum, with $S$. apache representing perhaps one out of every twenty specimens. Known from the forested mountain ranges located south of the transverse Mogollon Rim in central Arizona, we expect this species to be found further south through the northern Sierra Madre Occidental range and its northern Sky Islands.

\section{Strongylium atrum Champion, 1888}

(Fig. 3B, E)

Strongylium atrum Champion, 1888: 360; Triplehorn and Spilman 1973: 15; Bousquet et al. 2018: 319

Diagnosis. This species (Fig. 3B) can be recognized from all others of the region by having antennal article 3 subequal to 4 and the pronotum lacking a lateral margin (Fig. 3E) (pronotum margined laterally in $S$. apache and $S$. tenuicolle). Body concolorus, dull black, elytra very finely punctured.

Distribution. (Fig. 2) Known from southern Arizona, southwestern New Mexico in the United States and Chihuahua, Durango, and Sinaloa in Mexico (Triplehorn and Spilman 1973). New Records. Mexico: Sonora: 23.5 km WSW of Fronteras, Sierra Buenos Aires, 30.76167 -109.82361 [5 ASUHIC]; eastern side of Mazatán, 29.00472 -110.14806 [1 ASUHIC]; 9.4km (air) WSW Aconchi, Sierra Aconchi, 29.79833 -110.31972 [1 ASUHIC]; Rancho Las Avispas, 15.5 air km SW of Nogales, 31.19728 -111.10139 [2 ASUHIC]; $22.4 \mathrm{~km}$ (air) $\mathrm{N}$ of Nacozari de Garcia, $30.57556-109.7325$ [2 ASUHIC]; $17.2 \mathrm{~km} \mathrm{~N}$ of Nacozari de García, 30.53056 -109.72194 [1 ASUHIC]; Agua Zarca, S of Nogales, 31.16222 -110.95333 [1 ASUHIC]; $29.9 \mathrm{~km}$ E Cananea, 30.97283 -109.96075 [1 ASUHIC]; 6.5km SE Nacozari de Garcia, 30.32833 -109.62972 [2 ASUHIC]; Aconchi, Rancho los Alisos; 29.79833 -110.31972, $29.79833-110.31972$ [1 ASUHIC]; $14 \mathrm{~km} \mathrm{~W}$ of San Felipe de Jesús, 29.8778 -110.3883 [1 MAJC]; 12.3 mi E. Moctezuma, 29.842222 -109.492222 [1 MAJC]; Highway 16, 9.1 mi E + 1.8 mi SW Yecora, 28.370278 -109.031389 [1 MAJC]; $14.2 \mathrm{~km}$ (by air) SW of Bacanora, Sierra de Murrieta, 28.90111 -109.51417 [1 MAJC].

Remarks. This is the most abundant and widespread species in the region. The new records from Sonora were absolutely expected based on its previously known range, but the species is now confirmed to be widespread throughout the northern Sierra Madre Occidental region from middle to high elevation forested areas.

\section{Strongylium tenuicolle (Say, 1826)}

(Fig. 3C)

Helops tenuicollis Say, 1826: 241

Strongylium tenuicolle: Lacordaire 1859: 486; Horn 1870: 398; Triplehorn and Spilman 1973: 6; Bousquet et al. 2018: 323
Diagnosis. This species (Fig. 3C) can be recognized from all other species of Stenochiini of the region by having antennal article 3 subequal to 4 , pronotum with a lateral margin ( $S$. atrum lacking lateral margin), and the elytra with strial punctures in a continuous sulcus and the intervals convex ( $S$. apache without sulcate striae and with flat intervals). Body concolorous, subshining, black, pronotal length 80 percent or more pronotal width.

Distribution. (Fig. 4) Widespread in the United States and Canada east of the Rocky Mountains (Triplehorn and Spilman 1973, Bousquet et al. 2018). New Records. United States: Arizona: Greenlee County: SR78, 2mi S. NM State Line, 33.0989 -109.0707 [1 MAJC]. New Mexico: Gila County: FR153, 11mi NE Gila, 33.063408 -108.497552 [3 MAJC].

Remarks. A single specimen from Mescalero Sands, Chaves County was the first from New Mexico seen by us. This represented a new state record but was not particularly surprising given its previously known localities in the Jeff Davis Mountains of western Texas and Otero County, Colorado (Triplehorn and Spilman 1973). However, the records from Gila County, New Mexico and Greenlee County, Arizona represent the first known specimens of this species from west of the Continental Divide. This documented range extension raises the question of why it was not discovered previously. It is possible that it is due to insufficient historical collecting efforts, but it also may represent an introduction (possibly due to humans moving firewood), or it could represent a recent range extension of natural populations.

\section{EXTRALIMITAL SPECIES}

Oploptera simplicicollis (LeConte, 1878)

\section{New Combination}

(Fig. 1B)

Strongylium simplicicolle LeConte, 1878: 424; Triplehorn and Spilman 1973: 22; Bousquet et al. 2018: 323

Diagnosis. This species (Fig. 1B) is readily diagnosed from all other Stenochiini species in the United States by the antennal article 3 being about half as long as 4 (see key in Triplehorn and Spilman 1973). The pronotum entirely lacks a lateral margin. From its North American congeners treated by Champion (1888), it can be further diagnosed by having large eyes, males lacking a spine on the fore trochanter, the body being unicolorous, and the elytral striae not being crenate.

Distribution. (Fig. 4) This species is known from the southeastern United States (Triplehorn and Spilman 1973, Bousquet et al. 2018).

Remarks. This species, while seemingly quite geographically disjunct, is exceedingly similar to $O$. chamelensis. It can be separated by the pronotum with no lateral margin (margin evident in anterior $1 / 5$ in $O$. chamelensis) and the epistoma bearing punctures smaller than those of the frons and vertex (punctures similarly large in size in $O$. chamelensis). We examined three 
specimens from Missouri, USA and compared them with the treatment by Triplehorn and Spilman (1973) and with images of the holotype available from the Harvard Museum of Comparative Zoology available online (https://mcz. harvard.edu/).

\section{DISCUSSION}

Generic boundaries within Stenochiini have been considered doubtful by several generations of tenebrionid workers, particularly in the case of monophyly of the heterotypic Strongylium with respect to other North American genera (Triplehorn and Spilman 1973, Doyen 1989, 1990). It was this uncertainty that led Triplehorn and Spilman (1973: 5) to retain Oploptera simplicicollis in Strongylium. Nevertheless, Doyen (1990: 257) espoused the same uncertainty yet utilized the antennal characters to justify placement of his new species within Oploptera (there under the genus name Otocerus). Until Doyen (1990) treated the fauna around Chamela, Jalisco, Strongylium atrum was the only species known from north-central Mexico and essentially two distinct faunas have been considered in the literature: the 'Nearctic' from the United States and Canada, and the 'Central American' from southern Mexico through Panama. We are now faced with the facts that (1) Oploptera ranges much closer to the Nearctic fauna than previously reported, (2) the last comprehensive review of the tribe for North America maintained this genus as distinct from Strongylium (Doyen 1989: 301), and (3) we unfortunately lack any novel phylogenetic insights into this group beyond those known to the earlier cited authors. On balance, we believe that recognizing these two genera in a consistent manner will ultimately promote coherent generic concepts between these two groups of species historically treated separately and thereby ultimately begin to bring about taxonomic stability. It is in this understanding and the ease of diagnosing the short third antennal article that we justify the new placement of $O$. simplicicollis.

This study reports the first records of Stenochiini from Sonora. It mirrors the work of Doyen (1990) who similarly provided the first records of the tribe from Jalisco and enumerated nine species (seven named and two unnamed forms) spanning four genera. We here confirm two genera from Sonora comprising three species. We have also seen two forms of Strongylium from the vicinity of Alamos, Sonora which are not clearly diagnosable through the works of Doyen (1990) or Champion (1888) but seem to belong to a group of species with bright blue-green bodies and orange elytra that were identified with doubt or left unnamed by Doyen (1990). We expect more species will be enumerated from northwestern Mexico in the future, particularly in the forested regions of the Sierra Madre Occidental range and especially within the tropical deciduous forest biome which extends into southeastern Sonora as further collecting efforts increase and taxonomic works clarify species identities.
The bulk of material used in this study was derived from collecting efforts made on expeditions in Sonora, Mexico through the Madrean Discovery Expeditions. We are grateful to Thomas Van Devender and GreaterGood.org for coordinating these expeditions, many of which we have had the good fortune to participate in. We also thank Fredrick W. Skillman for providing valuable specimens, Warren E. Steiner and Kojun Kanda for productive discussion and specimen notes, and Nico Franz for coordinating field work within Sonora. This project was supported by the National Science Foundation award DEB-1754731.

\section{LITERATURE CITED}

Aalbu, R. L., C.A. Triplehorn, J.M. Campbell, K.W. Brown, R.E. Somerby and D. B. Thomas. 2002. 106. Tenebrionidae Latreille 1802. (pp. 463-509) in: Arnett, R.H., Thomas M.C., Skelley, P.E. and J.H. Frank (Eds.). American Beetles. Volume 2. Polyphaga: Scarabaeoidea through Curculionoidea. CRC Press, Boca Raton.

Bousquet, Y., D.B. Thomas, P. Bouchard, A.D. Smith, R.L. Aalbu, M.A. Johnston and W.E. Steiner. 2018. Catalogue of Tenebrionidae (Coleoptera) of North America. ZooKeys 728: 1-455. https://doi.org/10.3897/ zookeys. 728.20602

Champion, G.C. 1888. Insecta. Coleoptera. Vol. IV. Part 1. Heteromera (part). (pp. 353-476). In: Godman, F.D. and O. Salvin (Eds.) Biologia Centrali-Americana. Taylor and Francis, London.

Doyen, J.T. 1989. Reconstitution of Coelometopini, Tenebrionini and related tribes of America north of Colombia (Coleoptera: Tenebrionidae). Journal of the New York Entomological Society 97: 277-304. https:// www.jstor.org/stable/25009773

Doyen, J.T. 1990. Tenebrionidae and Zopheridae of the Chamela Biological Station and vicinity, Jalisco, Mexico (Coleoptera). Folia Entomologica Mexicana 77 [1988]: 211-276.

GBIF.org. 2021. GBIF Occurrence Download https://doi. org/10.15468/dl.7qjp47 Search date: February 10th, 2021.

Horn, G.E. 1870. Revision of the Tenebrionidae of America, north of Mexico. Transactions of the American Philosophical Society (Series 2) 14: 253-404. https:// doi.org/10.2307/1005214

Johnston, M.A., R.L. Aalbu and N.M. Franz. 2018. An updated checklist of the Tenebrionidae sec. Bousquet et al. 2018 of the Algodones dunes of California, with comments on checklist data practices. Biodiversity Data Journal 6: e24927. https://doi.org/10.3897/ BDJ.6.e24927

Johnston, M.A., A.D. Smith, K. Matsumoto and M.J. Kamiński. 2020. On the taxonomic placement of Penichrus Champion, 1885 and a synopsis of North American Opatrini (Coleoptera: Tenebrionidae: Blaptinae). Annales Zoologici 70(4): 765-774. https://

\section{ACKNOWLEDGEMENTS}


doi.org/10.3161/00034541ANZ2020.70.4.017

Lacordaire, J.T. 1859. Histoire naturelle des insectes.

Genera des Coléoptères ou exposé méthodique et critique de tous les genres proposés jusqu'ici dans cet ordre d'insectes. Tome cinquième. Contenant les familles des Ténébrionides, Cistélides, Nilionides, Pythides, Mélandryides, Lagriides, Pédilides, Anthicides, Pyrochroïdes, Mordellides, Rhipiphorides, Stylopides, Meloïdes et Oedémérides. Roret, Paris.

LeConte, J.L. 1878. Additional descriptions of new species. In: Schwarz, E.A. The Coleoptera of Florida. Proceedings of the American Philosophical Society 17: 373-434.

Recibido: 11 febrero 2021

Aceptado: 27 abril 2021
Say, T. 1826. Descriptions of new species of coleopterous insects inhabiting the United States. Journal of the Academy of Natural Sciences of Philadelphia 5[18251827]: 237-284.

Shorthouse, D.P. 2010. SimpleMappr, an online tool to produce publication-quality point maps. Available on: https://www.simplemappr.net. Search date: February 10th, 2021.

Triplehorn, C.A. and T.J. Spilman. 1973. A review of Strongylium of America North of Mexico, with descriptions of two new species (Coleoptera: Tenebrionidae). Transactions of the American Entomological Society 99(1): 1-27. https://www.jstor. org/stable/25078122 


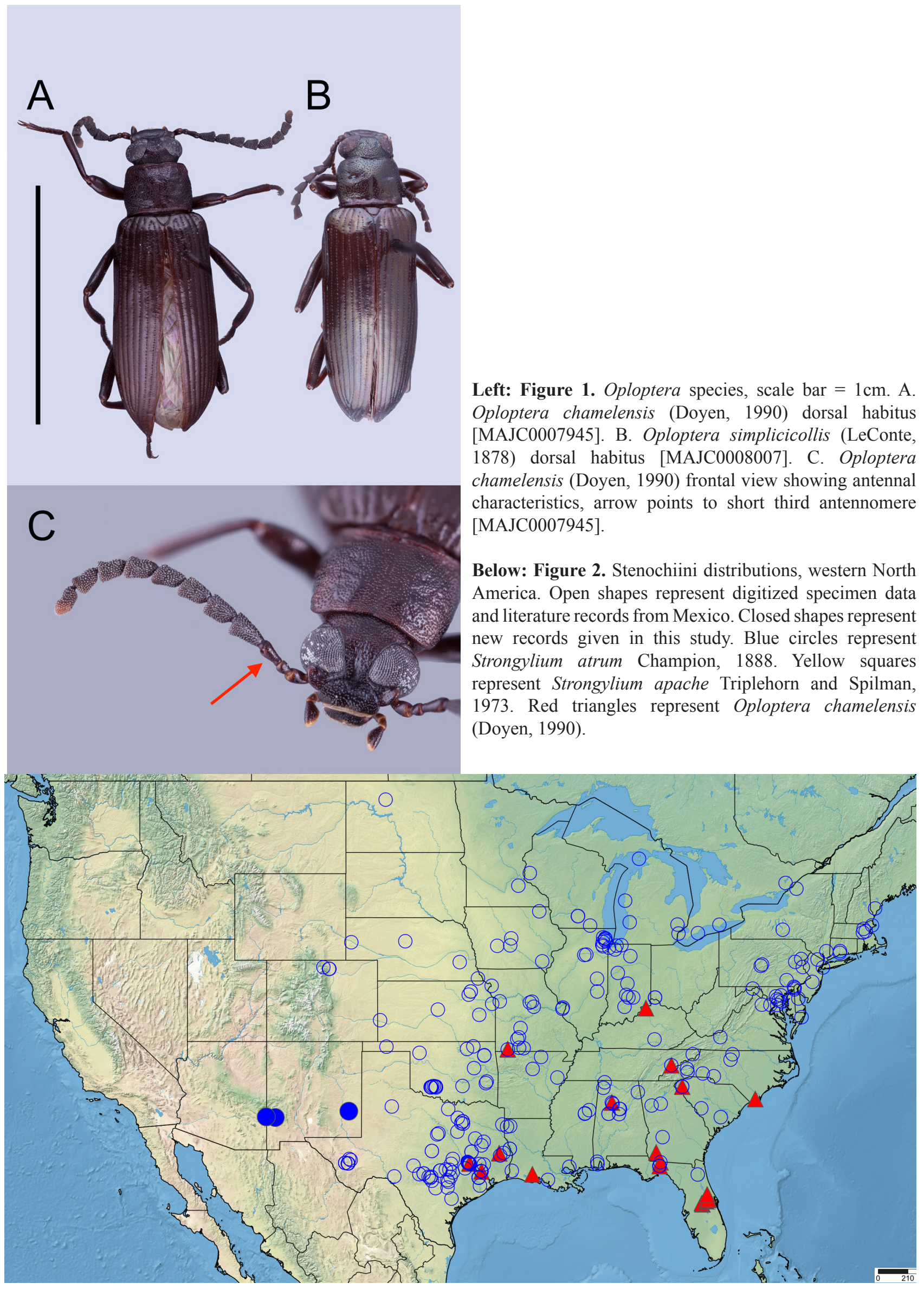




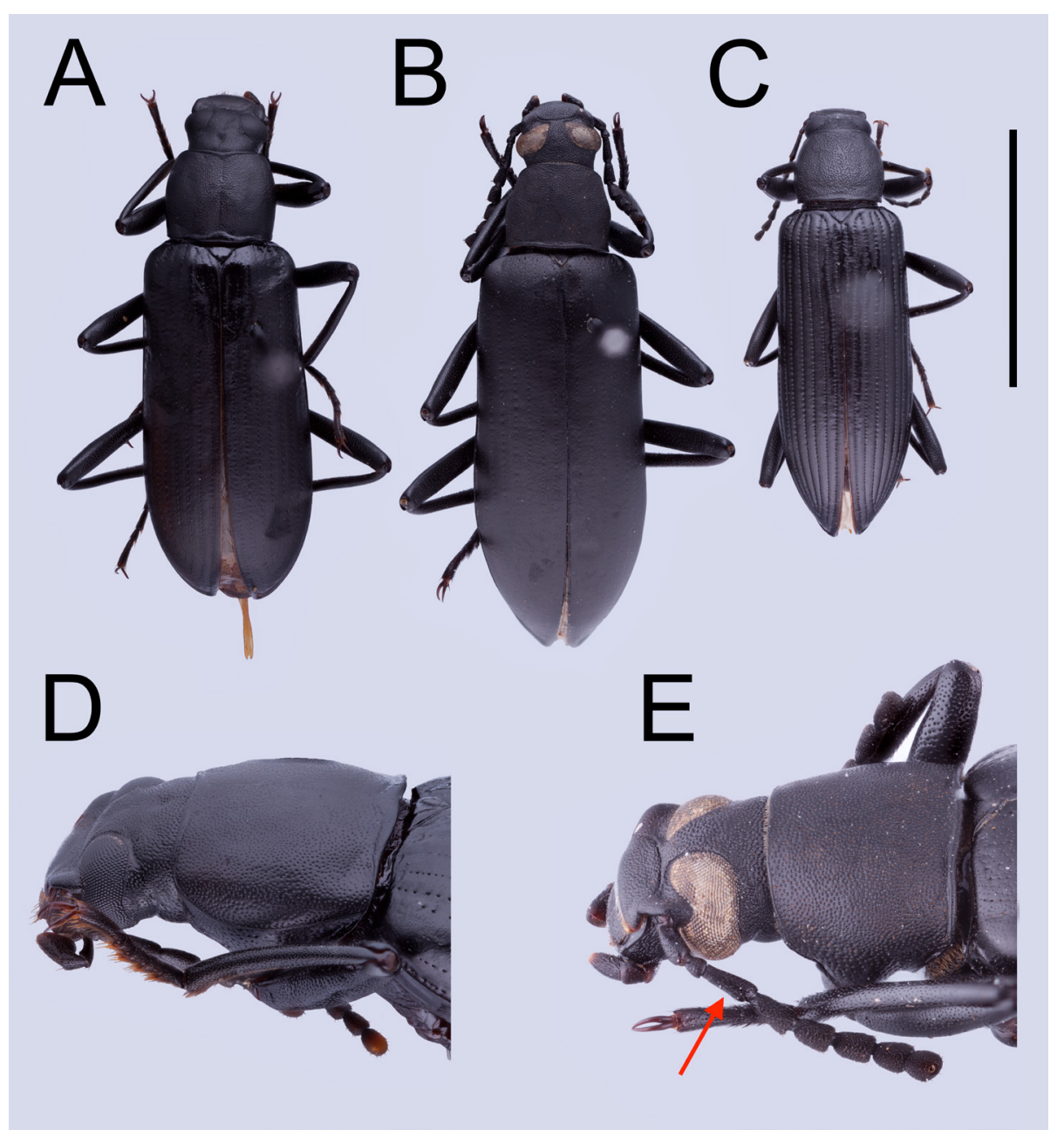

Left: Figure 3. Strongylium species, scale bar $=1 \mathrm{~cm}$. A. Strongylium apache Triplehorn and Spilman, 1973 dorsal habitus [MAJC0007943]. B. Strongylium atrum Champion, 1888 dorsal habitus [MAJC0007986]. C. Strongylium tenuicolle (Say, 1826) dorsal habitus [MAJC0007956]. D. Strongylium apache oblique lateral view showing longitudinal carina forming pronotal lateral margin [MAJC0007943]. E. Strongylium atrum oblique lateral view showing lack of lateral margin, arrow points to elongate third antennomere [MAJC0007986].

Below: Figure 4. Stenochiini distributions, eastern North America. Open shapes represent digitized specimen data and literature records from Mexico. Closed shapes represent new records given in this study. Blue circles represent Strongylium tenuicolle (Say, 1826). Red triangles represent Oploptera simplicicollis (LeConte, 1878).

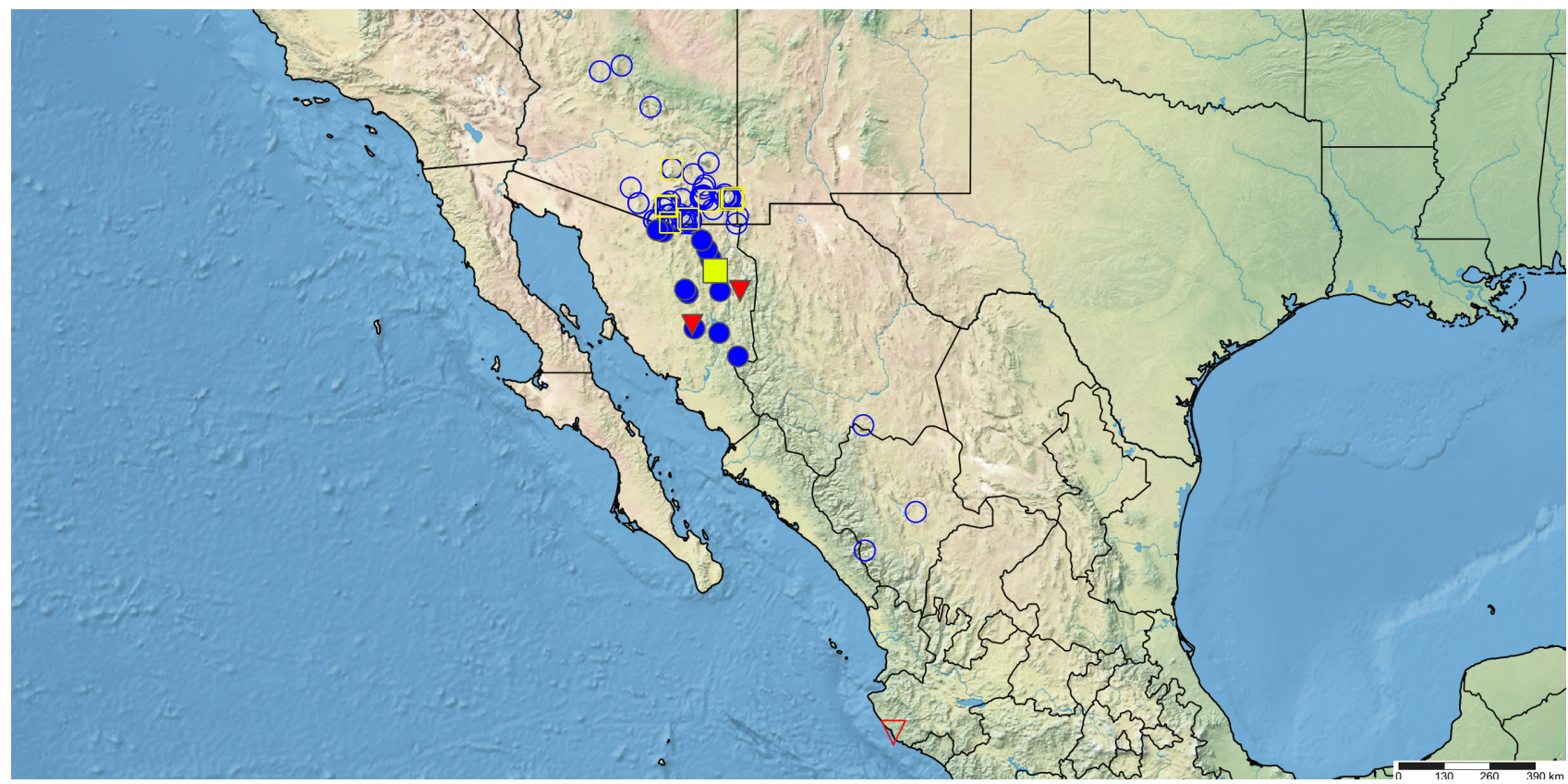

